\title{
Characterization of the insulin-antagonistic effect of growth hormone in man
}

\author{
J. Fowelin ${ }^{1}$, S. Attvall ${ }^{1}$,H.von Schenck ${ }^{2}$, U.Smith ${ }^{1}$ and I. Lager ${ }^{1}$ \\ ${ }^{1}$ Department of Medicine II, Sahlgren's Hospital, University of Göteborg, Göteborg and ${ }^{2}$ Department of Clinical Chemistry, \\ University of Linköping, Linköping, Sweden
}

Summary. The insulin-antagonistic effect of growth hormone was characterized by infusing the hormone at three different infusion rates $\left(6,12\right.$ or $\left.24 \mathrm{mU} \cdot \mathrm{kg}^{-1} \cdot \mathrm{min}^{-1}\right)$ for one $\mathrm{h}$ in 11 healthy subjects. The insulin effect was measured with the euglycaemic clamp technique combined with $\mathrm{D}-\left(3-{ }^{3} \mathrm{H}\right)$-glucose infusion to evaluate glucose production and utilization. A control study with $\mathrm{NaCl}\left(154 \mathrm{mmol} \cdot 1^{-1}\right)$ infusion was also performed. The insulin levels during the clamps were similar in all studies $\left(36 \pm 0.2 \mathrm{mU} \cdot 1^{-1}\right)$. Peak growth hormone levels were reached at $60 \mathrm{~min}$ (growth hormone $6 \mathrm{mU} \cdot \mathrm{kg}^{-1} \cdot \mathrm{h}^{-1}$ : $31 \pm 5$; growth hormone $12 \mathrm{mU} \cdot \mathrm{kg}^{-1} \cdot \mathrm{h}^{-1}: 52 \pm 4$ and growth hormone $\left.24 \mathrm{mU} \cdot \mathrm{kg}^{-1} \cdot \mathrm{h}^{-1}: 102 \pm 8 \mathrm{mU} \cdot 1^{-1}\right)$. The insulinantagonistic effect of growth hormone started after $\sim 2 \mathrm{~h}$, was maximal after $4-5 \mathrm{~h}(\sim 39 \%$ inhibition of glucose infusion rate between control and growth hormone $24 \mathrm{mU} \cdot \mathrm{kg}^{-1} \cdot \mathrm{h}^{-1}$ ) and lasted for 6-7 $\mathrm{h}$ after peak levels. The resistance was due to a less pronounced insulin effect both to inhibit glucose pro- duction and to stimulate glucose utilization. Growth hormone infusion of $12 \mathrm{mU} \cdot \mathrm{kg}^{-1} \cdot \mathrm{h}^{-1}$ induced a similar insulinantagonistic effect as the higher infusion rate whereas $6 \mathrm{mU} \cdot \mathrm{kg}^{-1} \cdot \mathrm{h}^{-1}$ induced a smaller response with a duration of $1 \mathrm{~h}$ between 3-4 $\mathrm{h}$ after peak levels of growth hormone. The present study demonstrates that growth hormone levels similar to those frequently seen in Type 1 (insulin-dependent) diabetic patients during poor metabolic control or hypoglycaemia, have pronounced insulin-antagonistic effects. The effects starts after about $2-3 \mathrm{~h}$, is maximal after $4-5 \mathrm{~h}$ and lasts for about $6-7 \mathrm{~h}$. Both duration and inhibitory effect of growth hormone are related to the plasma levels, where a maximal effect is seen at about $50 \mathrm{mU} \cdot 1^{-1}$ or higher.

Key words: Growth hormone, insulin resistance, glucose production, glucose utilization, dose response effect.
The effect of growth hormone $(\mathrm{GH})$ in diabetes mellitus has recently attracted much interest, not least since it may play an important role in the development of diabetic retinopathy [1]. In addition, GH has insulin-antagonistic effects [2-5] and elevated levels are frequently seen in Type 1 (insulin-dependent) diabetes during poor metabolic control [6-8]. Press et al. have also shown that diabetes control deteriorates when $\mathrm{GH}$ is infused in patients with Type 1 diabetes $[9,10]$.

Hypoglycaemia is a potent stimulus for GH release [11, 12] and may be another contributory reason for the frequently elevated GH levels in diabetic patients treated with insulin. GH is of importance for glucose counterregulation during prolonged hypoglycaemia $[13,14]$ and plays an important role for the late $(6-8 \mathrm{~h})$ post-hypoglycaemic insulin resistance $[15,16]$.

GH is usually secreted in a pulsatile manner. Pulses are regularly seen shortly after falling asleep $[8,17]$. These sleep-associated GH pulses seem to be important in the dawn phenomenon i.e., the decreased insulin sensitivity in the early morning $[17,18]$.
Most previous studies of the insulin-antagonistic effect of GH have used constant infusions with prolonged elevations of the blood levels $[3,4]$. The interpretation of such experimental designs in terms of normal physiology is, however, uncertain since GH is normally released in a pulsatile manner.

The aim of the present study was to characterize the insulin-antagonistic effect of GH given in short pulses. Growth hormone was infused for one hour at three different infusion rates to produce $\mathrm{GH}$ levels normally seen during mild, moderate or severe hypoglycaemia. The insulin response was concomitantly followed for $8 \mathrm{~h}$.

\section{Subjects and methods}

Eleven healthy subjects of normal weight and without any family history of diabetes participated in the study. The clinical characteristics of the subjects are shown in Table 1. None of the subjects was regularly taking any medication. Informed consent was obtained from all subjects and the study was approved by the Ethical Committee of the University of Göteborg. 
Table 1. Clinical characteristics of the subjects

\begin{tabular}{lllll}
\hline Sex & $\begin{array}{l}\text { Age } \\
\text { (years) }\end{array}$ & $\begin{array}{l}\text { Weight } \\
(\mathrm{kg})\end{array}$ & $\begin{array}{l}\text { Height } \\
(\mathrm{cm})\end{array}$ & $\begin{array}{l}\text { Body mass index } \\
\left(\mathrm{kg} / \mathrm{m}^{2}\right)\end{array}$ \\
\hline $\mathrm{M}$ & 21 & 74 & 175 & 24.2 \\
$\mathrm{M}$ & 21 & 86 & 194 & 20.5 \\
$\mathrm{M}$ & 24 & 63 & 188 & 17.8 \\
$\mathrm{M}$ & 24 & 77 & 178 & 24.3 \\
$\mathrm{M}$ & 27 & 79 & 178 & 24.9 \\
$\mathrm{M}$ & 29 & 87 & 180 & 26.8 \\
$\mathrm{M}$ & 34 & 65 & 175 & 21.2 \\
$\mathrm{M}$ & 34 & 77 & 192 & 20.9 \\
$\mathrm{~F}$ & 35 & 54 & 170 & 18.9 \\
$\mathrm{M}$ & 36 & 68 & 176 & 21.9 \\
$\mathrm{M}$ & 39 & 70 & 170 & 24.9 \\
Mean \pm SEM & $29 \pm 2$ & $73 \pm 3$ & $180 \pm 2$ & $22.4 \pm 0.8$ \\
\hline
\end{tabular}

All eleven subjects participated in the control study and the infusion study where $\mathrm{GH}$ was given as $24 \mathrm{mU} \cdot \mathrm{kg}^{-1} \cdot \mathrm{h}^{-1}$ (high). In addition, eight of them received a $\mathrm{GH}$ infusion of $12 \mathrm{mU} \cdot \mathrm{kg}^{-1} \cdot \mathrm{h}^{-1}$ (intermediate) and seven, an infusion of $6 \mathrm{mU} \cdot \mathrm{kg}^{-1} \cdot \mathrm{h}^{-1}$ (low). No subjects were excluded from the study but four individuals were unable to participate in all four studies due to work considerations. The infusion rates were given in a randomized order. Figure 1 summarizes the experimental protocol.

\section{Infusions}

All experiments were started after an overnight fast at 08.00 hours. The infusions were made via a catheter placed in a cubital vein and arterialized blood samples were drawn from a dorsal hand vein in the contralateral arm. Insulin (Actrapid Human, Novo-Nordisk, Copenhagen, Denmark) was dissolved in $\mathrm{NaCl}\left(154 \mathrm{mmol} \cdot \mathrm{1}^{-1}\right)$ to a concentration of $40 \mathrm{mU} \cdot \mathrm{ml}^{-1}$ with $4 \mathrm{mg} \cdot \mathrm{ml}^{-1}$ albumin added to prevent adhesion and infused at a rate of $0.5 \mathrm{mU} \cdot \mathrm{kg}^{-1} \cdot \mathrm{min}^{-1} \mathrm{dur}$ ing the euglycaemic clamps. Glucose $\left(200 \mathrm{mg} \cdot \mathrm{ml}^{-1}\right.$, Baxter Chemicals, Oslo, Norway), was infused at variable rates in the same catheter as insulin. Potassium chloride $\left(100 \mathrm{mmol} \cdot \mathrm{l}^{-1}\right)$ was infused at a rate of $5 \mathrm{mmol} \cdot \mathrm{h}^{-1}$ to prevent hypokalaemia during the clamps. Growth hormone, dissolved in $\mathrm{NaCl}$ to a concentration of $80 \mathrm{mU} \cdot \mathrm{ml}^{-1}$ (Genotropin, Ferring, Denmark), was randomly infused during the first hour of the study at one of the three different infusion rates of 6,12 or $24 \mathrm{mU} \cdot \mathrm{kg}^{-1} \cdot \mathrm{h}^{-1} \cdot \mathrm{NaCl}$ was used for the control study.

Rates of glucose appearance $(\mathrm{Ra})$ and disposal $(\mathrm{Rd})$ were determined by the infusion of D- $\left(3-{ }^{3} \mathrm{H}\right)$-glucose (New England Nuclear, Boston, Mass., USA) dissolved in $\mathrm{NaCl}$. A primed infusion of $25 \mu \mathrm{Ci}$ was given followed by a constant infusion of $15 \mu \mathrm{Cl} \cdot \mathrm{h}^{-1}$. After a $2 \mathrm{~h}$ equilibration period, the euglycaemic clamp was started with a primed insulin infusion for 10 min followed by a constant infusion during the following $6 \mathrm{~h}$ as reported previously [19].
During the clamp studies arterialized venous blood samples were drawn to measure blood glucose every $5 \mathrm{~min}$ with glucose teststrips (BM-test glycemie 1-44, Boehringer Mannheim, FRG) and a reflectometer (Reflolux II, Boehringer Mannheim). Glucose levels measured with the reflectometer correlated closely with both the YSI glucose analyser (Yellow Springs, Ohio, USA; $n=91, r=0.99$ ) and the glucose-6-phosphatase dehydrogenase technique $(n=1410$, $r=0.99$ ). The glucose levels were also measured with the glucose-6phosphatase dehydrogenase technique before the clamps and every 20 min during the clamps. The glucose levels in Results are those measured using this technique.

\section{Analytical procedures}

During the isotopic equilibration period, blood samples were drawn before and after 30,60,90,100,110,120 min and henceforth every $20 \mathrm{~min}$ for the chemical determination of glucose and measurements of specific activity. During the study, blood samples for the determination of glucose, insulin, growth hormone and non-esterified fatty acids (NEFA) were taken at the specified times. All samples were kept on ice and rapidly centrifuged. Plasma was stored at $-20^{\circ} \mathrm{C}$ until analysis.

Glucose levels were determined with glucose-6-phosphate dehydrogenase (Beckman, Fullerton, Calif., USA). Measurements of the specific activity of glucose were performed on plasma samples deproteinized with $\mathrm{Ba}(\mathrm{OH})_{2}$ and $\mathrm{ZnSO}_{4}$ and evaporated at $40^{\circ} \mathrm{C}$. The samples were counted in a liquid scintillation counter for $20 \mathrm{~min}$. Insulin was determined with a radioimmunoassay (Phadeseph Insulintest, Pharmacia, Uppsala, Sweden) and C-peptide with an in-house radioimmunoassay. GH was determined by a double antibody technique.

NEFA levels were analysed with a commercially available kit (NEFAC, Wako, Neuss, FRG). Glucose infusion rate (GIR), glucose production $(\mathrm{Ra})$ and utilization $(\mathrm{Rd})$ were measured throughout the $6 \mathrm{~h}$ clamp. Blood samples were drawn at $20 \mathrm{~min}$ intervals during the clamps and the values shown are the mean of the three samples taken every hour. Samples for insulin and $\mathrm{GH}$ analyses were drawn at $30 \mathrm{~min}$ intervals and the samples for C-peptide and NEFA were drawn every $60 \mathrm{~min}$.

$\mathrm{Ra}$ and $\mathrm{Rd}$ were calculated with the non-steady-state equations of de Bodo et al. [20]. This method assumes that rapid changes in the specific activity and concentrations of glucose do not occur uniformly within the entire glucose pool. To compensate for non-uniform mixing, the non-steady-state term of the equation was multiplied by a correction factor (pool fraction) of $0.65[21,22]$. Ra was calculated by subtracting the rates of infusion of exogenous glucose from the tracer determined total rate of glucose production.

\section{Statistical analysis}

Data are shown as means \pm SEM. Significant differences $(p<0.05)$ were determined with Student's two-tailed $t$-test for paired data using the method of multiple comparisons [23].

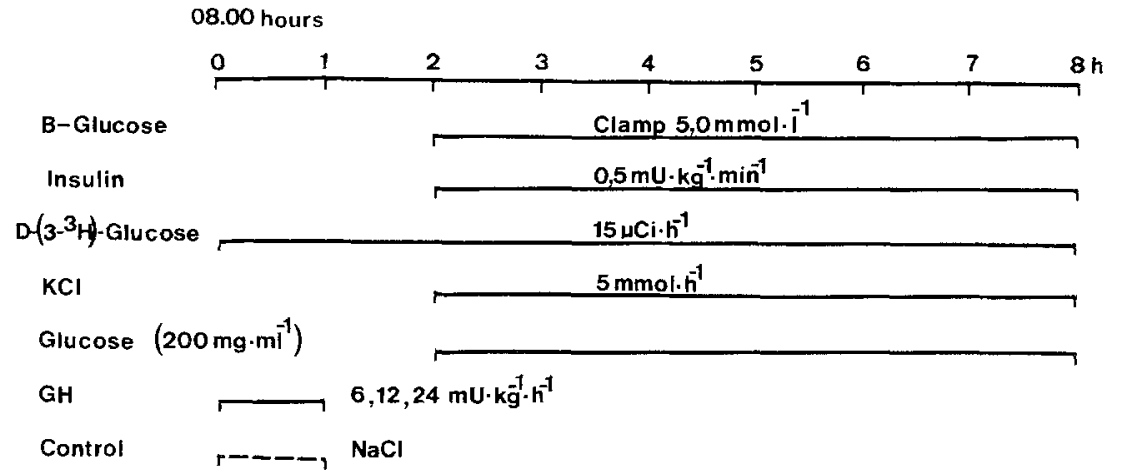

Fig. 1. Study design. Growth hormone (GH) was infused for $1 \mathrm{~h}$ at three different concentrations: 6,12 and $24 \mathrm{mU} \cdot \mathrm{kg}^{-1} \cdot \mathrm{h}^{-1}$. During the control study, $\mathrm{NaCl} 154 \mathrm{mmol} \cdot 1^{-}$ was infused. The growth hormone effects were evaluated during a euglycaemic clamp from the third to the eighth hour following the start of the GH infusion 


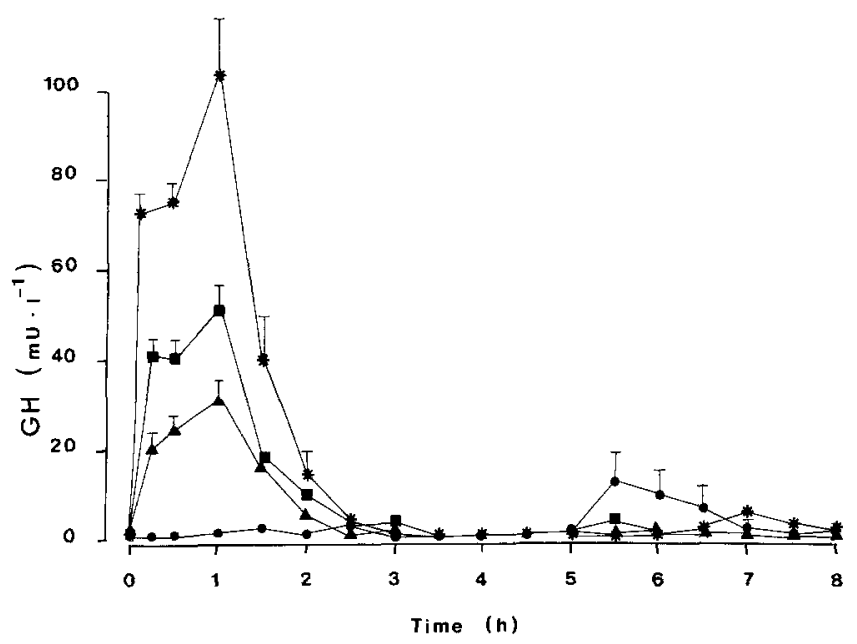

Fig. 2. Plasma growth hormone $(\mathrm{GH})$ levels during the infusions and throughout the euglycaemic clamps. Control (-), GH $6 \mathrm{mU}$. $\mathrm{kg}^{-1} \cdot \mathrm{h}^{-1}(\Delta), \mathrm{GH} 12 \mathrm{mU} \cdot \mathrm{kg}^{-1} \cdot \mathrm{h}^{-1}(\boldsymbol{v})$ and GH $24 \mathrm{mU} \cdot \mathrm{kg}^{-1} \cdot \mathrm{h}^{-1}$ (*)
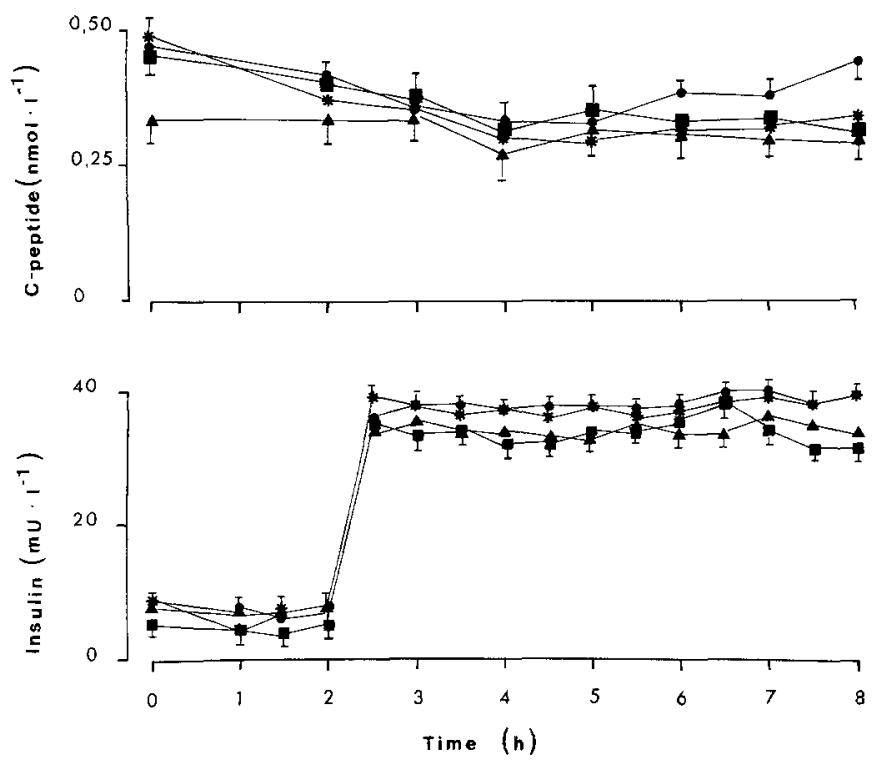

Fig. 3. Plasma levels of insulin and C-peptide during the studies. Control (@), growth hormone $(\mathrm{GH}) 6 \mathrm{mU} \cdot \mathrm{kg}^{-1} \cdot \mathrm{h}^{-1}(\boldsymbol{\Delta}), \mathrm{GH}$ $12 \mathrm{mU} \cdot \mathrm{kg}^{-1} \cdot \mathrm{h}^{-1}(\mathbf{a})$ and $\mathrm{GH} 24 \mathrm{mU} \cdot \mathrm{kg}^{-1} \cdot \mathrm{h}^{-1}(*)$

\section{Results}

\section{Glucose levels}

Fasting glucose levels were similar in all groups; control: $5.0 \pm 0.1$; low $\mathrm{GH}$ infusion $\left(6 \mathrm{mU} \cdot \mathrm{kg}^{-1} \cdot \mathrm{h}^{-1}\right)$ : $4.7 \pm 0.1$; intermediate $\mathrm{GH}$ infusion $\left(12 \mathrm{mU} \cdot \mathrm{kg}^{-1} \cdot \mathrm{h}^{-1}\right)$ : $4.7 \pm 0.1$; high $\mathrm{GH}$ infusion $\left(24 \mathrm{mU} \cdot \mathrm{kg}^{-1} \cdot \mathrm{h}^{-1}\right)$ : $4.9 \pm 0.1 \mathrm{mmol} \cdot 1^{-1}$. No differences were found in the glucose levels during and immediately following the $\mathrm{GH}$ infusions (control: $4.8 \pm 0.2$; low GH: $4.7 \pm 0.4$; intermediate GH: $4.7 \pm 0.4$ and high GH: $4.8 \pm 0.4 \mathrm{mmol} \cdot \mathrm{1}^{-1}$ ). During the clamps the blood glucose levels were similar in all studies (control: $4.9 \pm 0.2$; low GH: $4.8 \pm 0.3$; intermediate GH: $4.8 \pm 0.2$ and high GH: $4.9 \pm 0.2$ ) with coefficients of variation of $6.8 \pm 0.2,6.7 \pm 0.1,5.6 \pm 0.2$ and $5.2 \pm 0.2 \%$, respectively.
J. Fowelin et al:: The insulin-antagonistic effect of growth hormone

Hormone levels

The GH levels were low at the beginning of the studies 08.00 hours (control: $0.2 \pm 0.01(0.1 \pm 0.005)$; low GH: $2.0 \pm 1.0 \quad(1.0 \pm 0.5) ; \quad$ intermediate $\mathrm{GH}: \quad 2.4 \pm 1.5$ $(1.2 \pm 0.85)$; high GH: $1.1 \pm 0.7(0.6 \pm 0.4) \quad \mathrm{mU} \cdot 1^{-1}$ (ng $\left.\cdot \mathrm{ml}^{-1}\right)$ ). During the GH infusions (Fig. 2) peak levels were seen at $60 \mathrm{~min}$ (control: $2.8 \pm 0.8(1.4 \pm 0.4)$; low $\mathrm{GH}: 31 \pm 5(16 \pm 2)$; intermediate GH: $52 \pm 4(26 \pm 2)$ and high GH: $\left.102 \pm 8(51 \pm 4) \mathrm{mU} \cdot 1^{-1}\left(\mathrm{ng} \cdot \mathrm{ml}^{-1}\right)\right)$. No increase in GH levels was seen in the control study. After stopping the infusions, the GH-levels gradually decreased and had returned to pre-infusion levels at $150 \mathrm{~min}$ (Fig. 2). Small spontaneous GH-peaks were seen in all studies after 5 to $7 \mathrm{~h}$. However, there were no significant differences in the GH-levels between the studies after the initial $2 \mathrm{~h}$.

The insulin levels did not differ between the groups at the start of the experiments (control: $7 \pm 1$; low GH: $5 \pm 1$; intermediate $\mathrm{GH}: 7 \pm 1$; high $\mathrm{GH}: 8 \pm 1 \mathrm{mU} \cdot 1^{-1}$ ) or during the euglycaemic periods before the clamps. During the euglycaemic clamps, the insulin levels were maintained at high physiological levels and were not different between the studies (control: $38 \pm 0.3$; low GH: $34 \pm 0.6$; intermediate $\mathrm{GH}: 34 \pm 0.5$; high $\mathrm{GH}: 37 \pm 0.3 \mathrm{mU} \cdot 1^{-1}$ ) (Fig. 3). The $\mathrm{C}$-peptide levels were also similar before and during the clamps (Fig.3).

The NEFA levels (Fig.4) were similar at the beginning of the studies (control: 526 \pm 51 ; low GH: $625 \pm 93$; intermediate GH: $418 \pm 61$; high GH: $\left.490 \pm 77 \mathrm{mmol} \cdot 1^{-1}\right)$. Following the GH infusions, the NEFA-levels were higher than in the control study. However, during the insulin infusions similar levels were seen (Fig.4).

\section{Glucose infusion rates (GIR)}

Infusion of $\mathrm{GH}$ at 12 and $24 \mathrm{mU} \cdot \mathrm{kg}^{-1} \cdot \mathrm{h}^{-1}$, induced insulin resistance even during the first hour of the clamp (GIR control: $2.8 \pm 0.3$; intermediate GH: $2.3 \pm 0.3$; high GH: $2.2 \pm 0.2 \mathrm{mg} \cdot \mathrm{kg}^{-1} \cdot \mathrm{min}^{-1} ; p<0.02$ ) (Fig.5). No significant difference was seen in GIR between the control and low GH infusion during the first hour. The insulinantagonistic effect of $\mathrm{GH}$ increased during the following hour. Maximal inhibitory effects of the intermediate and high GH infusion were seen $4-5 \mathrm{~h}$ after peak levels (GIR control: $5.4 \pm 0.4$; intermediate GH: $3.7 \pm 0.4$; high $\mathrm{GH}$ : $\left.3.3 \pm 0.3 \mathrm{mg} \cdot \mathrm{kg}^{-1} \cdot \mathrm{min}^{-1}, p<0.001\right)$ and $3-4 \mathrm{~h}$ after peak levels at the low infusion rate (Fig.5).

The insulin-antagonistic effect of the intermediate and high $\mathrm{GH}$ infusions gradually decreased after $4-5 \mathrm{~h}$ and had a duration of about 6-7 $\mathrm{h}$ after the peak levels. At the low GH infusion rate the insulin resistance only lasted for $1 \mathrm{~h}$ between 3-4 $\mathrm{h}$ after peak levels of GH.

When the maximal insulin-antagonistic effect of growth hormone (= difference in GIR between control and $\mathrm{GH}$ ) was plotted as a function of the peak $\mathrm{GH}$ levels, the dose-response relationship illustrated in Figure 6 was obtained. GH levels of $102 \pm 8(51 \pm 4) \mathrm{mU} \cdot 1^{-1}\left(\mathrm{ng} \cdot \mathrm{ml}^{-1}\right)$ did not induce a greater insulin resistance than that seen at $52 \pm 4(26 \pm 2) \mathrm{mU} \cdot 1^{-1}\left(\mathrm{ng} \cdot \mathrm{ml}^{-1}\right)$. This dose-response re- 


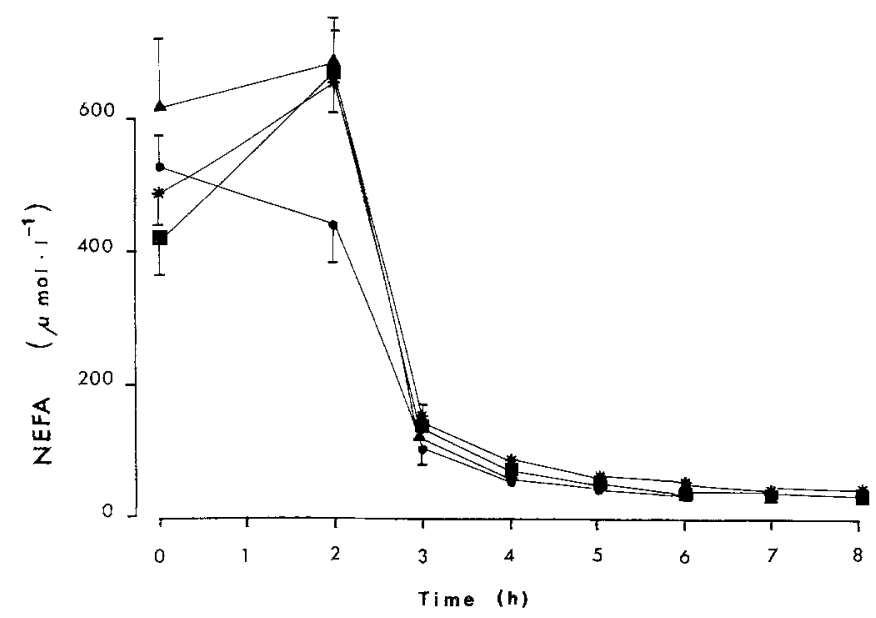

Fig.4. Non-esterified fatty acid (NEFA) levels during the studies. Control (•) growth hormone $(\mathrm{GH}) 6 \mathrm{mU} \cdot \mathrm{kg}^{-1} \cdot \mathrm{h}^{-1}(\boldsymbol{\Delta}), \mathrm{GH}$ $12 \mathrm{mU} \cdot \mathrm{kg}^{-1} \cdot \mathrm{h}^{-1}(\mathbf{a})$ and $\mathrm{GH} 24 \mathrm{mU} \cdot \mathrm{kg}^{-1} \cdot \mathrm{h}^{-1}(*)$

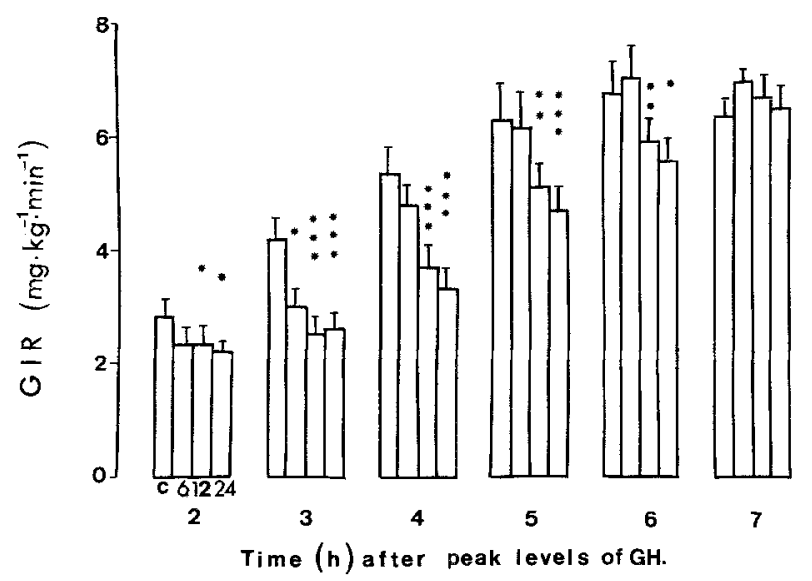

Fig. 5. Glucose infusion rates (GIR) during the euglycaemic clamps from 2 to $7 \mathrm{~h}$ following the peak levels of growth hormone $(\mathrm{GH})$ or in the control $\mathrm{NaCl} 154 \mathrm{mmol} \cdot \mathrm{1}^{-1}$ study. Control $=\mathrm{C}, 6=6 \mathrm{mU}$. $\mathrm{kg}^{1} \cdot \mathrm{h}^{-1}, \quad 12=12 \mathrm{mU} \cdot \mathrm{kg}^{-1} \cdot \mathrm{h}^{-1} \quad$ and $\quad 24=24 \mathrm{mU} \cdot \mathrm{kg}^{-1} \cdot \mathrm{h}^{-1}$. $* p<0.05$, ** $p<0.01$, *** $p<0.001$ vscontrol

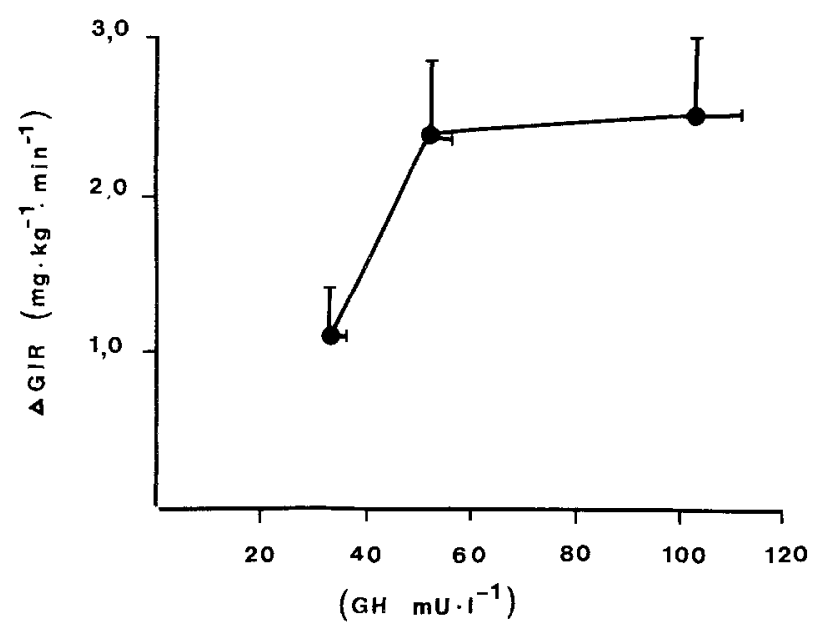

Fig.6. Maximal insulin-antagonistic effect ( $\triangle$ glucose infusion rate (GIR) = difference in GIR between control and growth hormone $(\mathrm{GH})$ studies) as a function of peak growth hormone levels during the three infusion rates $\left(6 \mathrm{mU} \cdot \mathrm{kg}^{-1} \cdot \mathrm{h}^{-1}: 31 \pm 5 ; 12 \mathrm{mU} \cdot \mathrm{kg}^{-1} \cdot \mathrm{h}^{-1}\right.$ : $\left.52 \pm 4 ; 24 \mathrm{mU} \cdot \mathrm{kg}^{-1} \cdot \mathrm{h}^{-1}: 102 \pm 8 \mathrm{mU} \cdot 1^{-1}\right)$ lationship was valid also in terms of duration of the insulin-antagonistic effect (Fig.5).

\section{Glucose production ( $R a)$ and utilization $(R d)$}

Glucose production rates were similar in all studies before the clamps (control: $2.2 \pm 0.1$; low GH: $2.0 \pm 0.2$; intermediate GH: $2.0 \pm 0.4$; high GH: $2.6 \pm 0.3 \mathrm{mg} \cdot \mathrm{kg}^{-1}$. $\min ^{-1}$ ) (Fig. 7). The glucose production rates decreased during the clamps but the decrease was less pronounced after the high GH infusion rate (Fig. 7). Slight negative Ra values were seen during the later part of the studies but the deviations from zero were not significant. Glucose utilization rates increased during the clamps in all studies but the increase was less pronounced after $\mathrm{GH}$ infusion (Fig.7). The average insulin-antagonistic effect of GH on $\mathrm{Ra}$ was small $\left(6 \mathrm{mU} \cdot \mathrm{h}^{-1} \quad 0.3 \%, 12 \mathrm{mU} \cdot \mathrm{h}^{-1} 3.8 \%\right.$, $24 \mathrm{mU} \cdot \mathrm{h}^{-1} 20.0 \%$ ) while the effect on Rd was much more pronounced $\left(6 \mathrm{mU} \cdot \mathrm{h}^{-1} 12 \%, 12 \mathrm{mU} \cdot \mathrm{h}^{-1} 40 \%\right.$, $24 \mathrm{mU} \cdot \mathrm{h}^{-1} 60 \%$ ).

\section{Discussion}

The aim of the present study was to characterize the GH levels required to elicit insulin resistance as well as its duration and time of onset. The results clearly suggest that even normal diurnal GH peaks $\left(\sim 30-50(\sim 15-25) \mathrm{mU} \cdot \mathrm{l}^{-1}\right.$ $\left.\left(\mathrm{ng} \cdot \mathrm{ml}^{-1}\right)\right)$, particularly high peaks are seen after falling asleep; $[8,15,17]$ can impair insulin action. This has also been found in the dawn phenomenon i.e. a decreased insulin effect in the early morning [18]. The elevated levels during hypoglycaemia or in poor diabetic control are also likely to play an important role in the enhanced insulin resistance seen in these conditions [13, 14, 24]. This conclusion has important ramifications in terms of interpreting the now established association between hyperglycaemia and insulin resistance $[25,26]$. It is clear that this association must be examined under conditions where the effect of the counterregulatory hormones, including $\mathrm{GH}$, is taken into account.

Growth hormone exerts both insulin-like and insulinantagonistic effects in vitro $[27,28]$. An insulin-like effect has been reported in some in vivo studies $[29,30]$, but not in all [31]. In the present study, the glucose, insulin and C-peptide levels were similar in all groups during the $2 \mathrm{~h}$ preceding the clamps when $\mathrm{GH}$ was infused. Our data do not support an important insulin-like effect of GH on glucose metabolism during moderate hyperinsulinaemia.

The insulin-antagonistic effect of growth hormone takes about $2-3 \mathrm{~h}$ to develop. In the study by BratuschMarrain et al. [2] using a higher insulin infusion rate than in the present study, no insulin-antagonistic effect of GH was found after $2 \mathrm{~h}$. In contrast, a clear effect within $2 \mathrm{~h}$ was found by Möller et al. with the forearm technique [31]. In the present study, insulin resistance was seen $2 \mathrm{~h}$ after ( $\mathrm{iH}$ was administered at the high infusion rate and after i h with the low infusion rate. The initial insulin-antagonistic effect of $\mathrm{GH}$ during the two higher infusion rates 

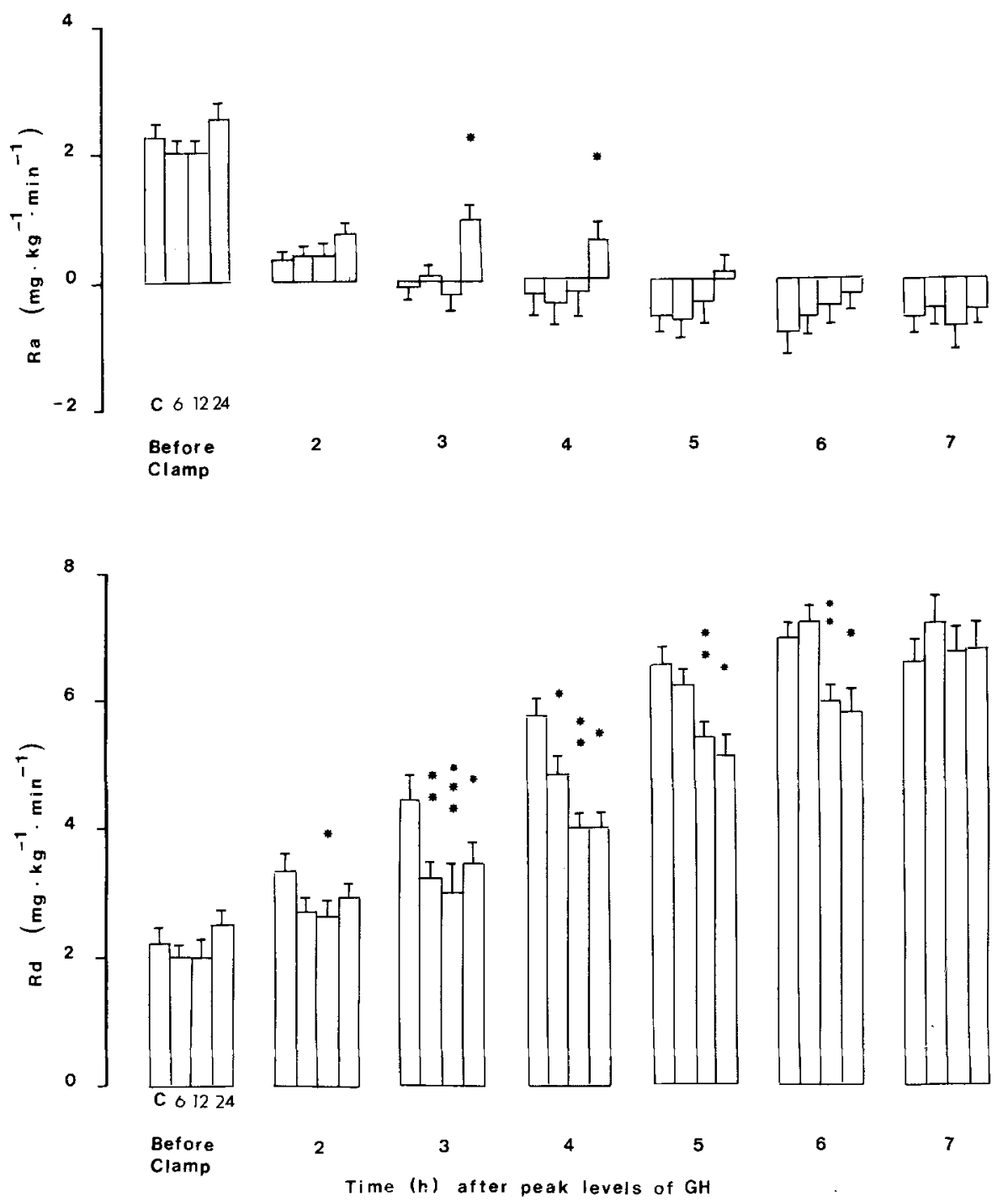

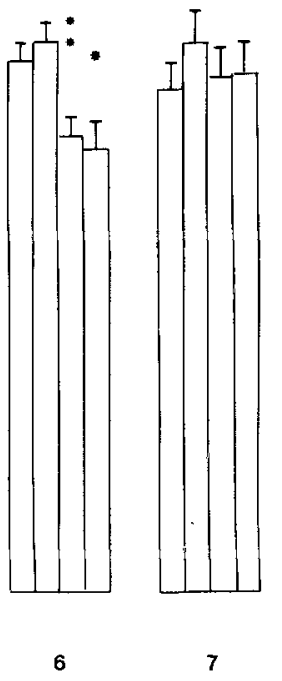

Fig. 7. Glucose production ( $\mathrm{Ra})$ and utilization $(\mathrm{Rd})$ during the euglycaemic clamps from 2 to $7 \mathrm{~h}$ following the peak levels of growth hormone $(\mathrm{GH})$ or in the control study. Control (C), GH infusions of $6 \mathrm{mU} \cdot \mathrm{kg}^{-1} \cdot \mathrm{h}^{-1}(6), 12 \mathrm{mU} \cdot \mathrm{kg}^{-1} \cdot \mathrm{h}^{-1}(12)$ and $24 \mathrm{mU} \cdot \mathrm{kg}^{-1} \cdot \mathrm{h}^{-1}(24)$. * $p<0.05$, ** $p<0.01$, *** $p<0.001$ vs control must, however, be interpreted with some caution as the clamps began $2 \mathrm{~h}$ following the start of the GH infusions. Thus, different results may depend on the experimental designs, in particular the ambient $\mathrm{GH}$ and insulin levels during the infusions.

The maximal inhibitory effect of $\mathrm{GH}$ was found $\sim 4 \mathrm{~h}$ after the peak levels. However, the duration of the insulin resistance was related to the peak levels reached. Peaks of $50(25) \mathrm{mU} \cdot \mathrm{1}^{-1}\left(\mathrm{ng} \cdot \mathrm{ml}^{-1}\right)$ or higher produced a sustained inhibitory effect for $6-7 \mathrm{~h}$ after stopping the $\mathrm{GH}$ infusion. This finding corresponds well with the duration of the late post-hypoglycaemic insulin resistance which is around $6-8 \mathrm{~h} \mathrm{[16]}$. In other studies where the duration of the $\mathrm{GH}$ effect was reported to be much longer $[9$, 32], higher GH levels were produced and, more importantly, the hormone was infused for a longer period of time [9].

The $\mathrm{GH}$ levels tended to increase late during the clamps in some control subjects. However, since this increase occurred during the end of the study, an effect on glucose metabolism during the last hour seems unlikely. This is also supported by the unchanged GIR during the last $2 \mathrm{~h}$ of the control study.
The most pronounced insulin-antagonistic effect of GH was seen on glucose utilization in the present study. Similar results were reported by Bratusch-Marrain et al. [2], whereas Rizza et al. [3] also found a pronounced effect on glucose production. It is difficult to directly compare the results from studies where different insulin and GH levels have been used. The liver is exquisitely sensitive to insulin $[33,34]$ and small differences can, therefore, influence the results. Also, in the present study, GH was found to antagonize the inhibitory effect of insulin on glucose production. However, since all subjects were very sensitive to insulin the effect on glucose utilization was quantitatively predominant. A similar pattern was also recently found during the late post-hypoglycaemic insulin resistance $[15,35]$.

Infusion of GH increased the plasma NEFA levels. It is unlikely that this is due to a direct lipolytic effect of $\mathrm{GH}$ since such an effect has been difficult to demonstrate with human fat cells in vitro [36]. However, the elevated NEFA levels may be caused by an insulin resistance and an attenuated glucose uptake by the fat cells, reducing the reesterification of the NEFA and, thus, enhancing NEFA release [37]. A similar effect has been demonstrated for 
cortisol. Irrespective of mechanisms, however, the elevated NEFA levels may have metabolic repercussions since this may lead to a decreased glucose utilization during moderate hyperinsulinaemia through the "glucoseNEFA-cycle" [38]. However, an important effect of NEFA on the insulin resistance elicited by GH is unlikely since the duration of the GH effect was prolonged and persisted long after the NEFA levels had become similar to those in the control study.

In conclusion, the present study demonstrates that $\mathrm{GH}$ peak levels similar to those usually seen in Type 1 diabetic patients during poor metabolic control or during hypoglycaemia, have pronounced insulin-antagonistic effects. The effect starts after about $2-3 \mathrm{~h}$ and has a duration of about $6-7 \mathrm{~h}$ after the peak level. Both duration and inhibitory effect are related to plasma levels, where a maximal effect is produced at about $50(25) \mathrm{mU} \cdot \mathrm{l}^{-1}\left(\mathrm{ng} \cdot \mathrm{ml}^{-1}\right)$ or higher.

Acknowledgements. The skillful assistance of Ms. R. Bittner, RN, is gratefully acknowledged. Excellent secretarial help was given by Ms. $\mathrm{K}$. Torstensson. GH was determined by a double antibody technique (kindly performed by Prof. G.Lindstedt, Dept. of Clinical Chemistry). This study was supported by grants from the Swedish Medical Research Council (project B-3506), The Gothenburg Medical Association, Nordisk Insulinfund and The Gothenburg Diabetes Association.

\section{References}

1. Sharp PS, Foley K, Vitelli F, Maneschi F, Kohner EM (1984) Growth hormone response to hyperinsulinaemia in insulin-dependent diabetics. Comparison of patients with and without retinopathy. Diab Med 1: 55-58

2. Bratusch-Marrain PR, Smith D, DeFronzo RA (1982) The effect of growth hormone on glucose metabolism and insulin secretion in man. J Clin Endocrinol Metab 55: 973-982

3. Rizza RA, Mandarino LJ, Gerich JE (1982) Effects of growth hormone on insulin action in man. Mechanisms of insulin resistance, impaired suppression of glucose production, and impaired stimulation of glucose utilization. Diabetes 31: 663-669

4. Sherwin RS, Schulman GA, Hendler R, Walesky M, Belous A, Tamborlane M (1983) Effect of growth hormone on oral glucose tolerance and circulating metabolic fuels in man. Diabetologia 24: 155-161

5. Kollind M, Adamson U, Lins PE, Efendic S (1987) Diabetogenic action of $\mathrm{GH}$ and cortisol in insulin-dependent diabetes mellitus. Aspects of the mechanisms behind the Somogyi phenomenon. Horm Metabol Res 19: 156-159

6. Johansen K, Hansen AaP (1969) High 24-hour level of serum growth hormone in juvenile diabetics. Br Med J 2: 356-357

7. Hayford JT, Danney MM, Hendrix JA, Thompson RG (1980) Integrated concentration of growth hormone in juvenile-onset diabetes. Diabetes 29: 391-398

8. Asplin CM, Faria ACS, Carlsen EC, Vaccaro VA, Barr RE, Iranmanesh A, Lee MM, Veldhuis JD, Evans WS (1989) Alterations in the pulsatile mode of growth hormone release in men and women with insulin-dependent diabetes mellitus. J Clin Endocrinol Metabol 69: 239-245

9. Press M, Tamborlane WV, Sherwin RS (1984) Importance of raised growth hormone levels in mediating the metabolic derangements of diabetes. N Engl J Med 310: 810-815

10. Press M, Tamborlane WV, Sherwin RS (1986) Effect of insulin on growth hormone-induced metabolic derangements in diabetes. Metabolism 35: 956-959
11. Cryer PE, Gerich JE (1985) Glucose counterregulation, hypoglycemia, and intensive insulin therapy in diabetes mellitus. $\mathrm{N}$ Engl J Med 313: 232-241

12. Attvall S, Eriksson B-M, Fowelin J, von Schenck H, Lager I, Smith U (1987) Early posthypoglycemic insulin resistance in man is mainly an effect of $\beta$-adrenergic stimulation. J Clin Invest 80: 437-442

13. De Feo P, Perriello G, Torlone E, Ventura MM, Santeusanio F, Brunetti P, Gerich JE, Bolli GB (1989) Demonstration of a role for growth hormone in glucose counterregulation. Am J Physiol 256: E835-E843

14. Boyle PI, Cryer PE (1991) Growth hormone, cortisol, or both are involved in defense against, but are not critical to recovery from hypoglycaemia. Am J Physiol 260: E395-E402

15. Fowelin J, Attvall S, von Schenck H, Smith U, Lager I (1989) Combined effect of growth hormone and cortisol on late posthypoglycemic insulin resistance in humans. Diabetes 38: 13571364

16. Fowelin J, Attvall S, von Schenck H, Smith U, Lager I (1990) Postprandial hyperglycaemia following a morning hypoglycaemia in Type 1 diabetes mellitus. Diab Med 7:156-161

17. Bolli GB, Gerich JE (1984) The "dawn phenomenon" - a common occurrence in both non-insulin-dependent and insulindependent diabetes mellitus. N Engl J Med 310: 746-750

18. Perriello G, De Feo P, Torlone E, Fanelli C, Santeusanio F, Brunetti P, Bolli GB (1990) Nocturnal spikes of growth hormone secretion cause the dawn phenomenon in Type 1 (insulin-dependent) diabetes mellitus by decreasing hepatic (and extrahepatic) sensitivity to insulin in the absence of insulin waning. Diabetologia 33: $52-59$

19. Lager I, Attvall S, Eriksson BM, von Schenck H, Smith U (1986) Studies on the insulin-antagonistic effect of catecholamines in normal man. Evidence for the importance of $\beta_{2}$-receptors. Diabetologia 29: 409-416

20. De Bodo RC, Steele R, Altszuler N, Dunn A, Bishop JS (1963) On the hormonal regulation of carbohydrate metabolism; studies with $\mathrm{C}^{14}$ glucose. Rec Prog Horm Res 19: 445-488

21. Cowan JS, Hetenyi G Jr (1971) Glucoregulatory responses in normal and diabetic dogs recorded by a new tracer method. Metabolism 20: 360-372

22. Radziuk J, Norwich KH, Vranic M (1978) Experimental validation of measurements of glucose turnover in nonsteady state. Am J Physiol 234: E84-E93

23. Holm S (1979) A simple sequentially rejective multiple test procedure. Scand J Stat 6: 65-70

24. Barett EJ, DeFronzo RA, Bevilacqua S, Ferrannini E (1982) Insulin resistance in diabetic ketoacidosis. Diabetes 31: 923-928

25. Yki-Järvinen H (1990) Acute and chronic effects of hyperglycaemia on glucose metabolism. Diabetologia 33: 579-585

26. Yki-Järvinen H, Koivisto VA (1984) Insulin sensitivity in newly diagnosed Type 1 diabetics after ketoacidosis and after three months of insulin therapy. J Clin Endocrinol Metabol 59: 371378

27. Björgell P, Rosberg S, Isaksson O, Belfrage P (1984) The antilipolytic, insulin-like effect of growth hormone is caused by a net decrease of hormone-sensitive lipase phosphorylation. Endocrinology 115: 1151-1156

28. Rosenfeld RG, Wilson DM, Dollar LA, Bennett A, Hintz RL (1982) Both human pituitary growth hormone and recombinant DNA-derived human growth hormone cause insulin resistance at a postreceptor site. J Clin Endocrinol Metab 54: 10331038

29. MacGorman LR, Rizza RA, Gerich JE (1981) Physiological concentrations of growth hormone exert insulin-like and insulin antagonistic effects on both hepatic and extrahepatic tissues in man. J Clin Endocrinol Metab 53:556-559

30. Adamson U, Efendic S (1979) Insulin-like and diabetogenic effects of growth hormone in healthy subjects, diabetics, and low insulin responders. J Clin Endocrinol Metab 49: 456-461

31. Möller N, Jörgensen JOL, Schmitz O, Möller J, Christiansen JS, Alberti KGMM, Örskov H (1990) Effects of a growth hormone 
pulse on total and forearm substrate fluxes in humans. Am J Physiol 258: E86-E91

32. Adamson U, Cerasi $E$ (1975) Acute effects of exogenous growth hormone in man: time- and dose-bound modification of glucose tolerance and glucose-induced insulin release. Acta Endocrinol 80: 247-261

33. Rizza RA, Mandarino LJ, Gerich JE (1981) Dose-response characteristics for effects of insulin on production and utilization of glucose in man. Am J Physiol 240: E630-E639

34. Nurjhan N, Campbell PJ, Kennedy FP, Miles JM, Gerich JE (1986) Insulin dose-response characteristics for suppression of glycerol release and conversion to glucose in humans. Diabetes 35: 1326-1331

35. Fowelin J, Attvall S, von Schenck H, Smith U, Lager I (1990) Characterization of the late posthypoglycemic insulin resistance in insulin-dependent diabetes mellitus. Metabolism 39: 822-826

36. Goodman HM (1970) Antilipolytic effects of growth hormone. Metabolism 19:849-855
37. Nyberg G, Smith U (1977) Human adipose tissue in culture. VII. The long-term effect of growth hormone. Horm Metab Res 9:22-27

38. Randle PJ, Garland PB, Hales CN, Newsholme EA (1963) The glucose fatty-acid cycle. Its role in insulin sensitivity and the metabolic disturbances of diabetes mellitus. Lancet I: 785-789

Received: 6 November 1990

and in revised form: 5 March 1991

Dr. J. Fowelin

Department of Medicine II

Sahlgren's Hospital

S-41345 Gothenburg

Sweden 